\title{
Detection of raspberry honey adulterated with agave, maple, rice, corn and inverted sugar syrups using instrumental techniques
}

\author{
Paula Ciursa, Mircea Oroian, Daniela Pauliuc
}

\author{
Stefan cel Mare University of Suceava, Romania
}

Keywords:
Honey
Respberry
Syrup
Electronic tongue

Article history:

Received

21.12.2020

Received in revised form 17.05.2021

Accepted

30.09.2021

\section{Corresponding author:}

Mircea Oroian

E-mail:

m.oroian@fia.usv.ro

DOI:

$10.24263 / 2304-$

974X-2021-10-3-5

\section{Abstract}

Introduction. Honey adulteration has negative effects from a financial and health point of view. In this work, the usefulness of the electronic tongue consisting of copper working electrode, in correlation with physico-chemical properties in the detection of adulterated honey with agave, maple, inverted sugar, cornand rice syrups is presented.

Materials and methods. Honey samples adulteration was done by adding syrup in different percentages: $5,10,20$ and $50 \%(\mathrm{w} / \mathrm{w})$. Physicochemical parameters analyzed were: color, moisture content, $\mathrm{pH}$, free acidity, electrical conductivity and hiroxymethylfurfural content (HMF). The measuring system was a PGSTAT with FRA32M module coupled with three electrodes: reference electrode $(\mathrm{Ag} / \mathrm{AgCl})$, counter electrode (platinum) and working electrode (copper).

Results and discussion. Honey adulteration has significantly influenced both physicochemical and voltametric tongue parameters. There was changes depending on the adulteration agent but also depending on the degree of adulteration. Adulterated honey with inverted sugar syrup presented the highest value of $\mathrm{L}^{*}$ parameter (33.14), in opposite with the lowest value in case of adulterated honey with rice syrup (27.10). The moisture content increased from $16.16 \%$ in authentic honey to $19.28 \%$ in adulterated honey with 50\% syrup. The magnitude of $\mathrm{pH}$ decrease in adulterated honey with inverted sugar syrup, due to the presence of added citric acid. The higher increase in the value of HMF content was from $58.09 \mathrm{mg} / \mathrm{kg}$ in authentic honey to $185.07 \mathrm{mg} / \mathrm{kg}$ in adulterated honey with inverted sugar syrup. As respects to voltammetric tongue, the current intensity value for authentic honey was $0.192 \mathrm{~mA}$. Pure maple and rice syrups presented the highest values, while the lowest were for the other three types of syrup. Regardless of the adulteration agent used, the fluctuations of the current intensity were highlighted starting from the adulteration degree of 5\% with the copper electrode. According to Principal component analysis (PCA), the first component (PC-1) represented $88 \%$ of the variance and the second component (PC-2) $11 \%$, totaling $99 \%$ of the initial variability. Adulterated honey samples with 5, 10 and $20 \%$ agave syrup, 5 and $10 \%$ corn syrup as well as $5 \%$ maple syrup are close to authentic honey.

Conclusions. Physicochemical parameters (color, $\mathrm{pH}$, moisture content, free acidity, electrical conductivity, HMF content) can be used as a preliminary analysis, but by coupling the voltammetric tongue with it have proven their usefulness in detecting adulterated honey samples with different adulteration agents even at $5 \%$. 


\section{Introduction}

Electronic tongue is a device consisting of a group of sensors used in identification and classification the tastes of chemicals in various food samples in the liquid phase but can also be used in the qualitative and quantitative characterization of multicomponent mixtures (Peris et al., 2016). The application and development of electronic tongue is based on different electrochemical techniques: potentiometry, voltammetry, impedance, conductometry, spectrophotometry etc. (Bougrini at el., 2016; Ha et al., 2015). Chemometric instruments have an essential role in recognizing the pattern of electronic tongue, being responsible for translating multivariate signals (Shimizu et el., 2020).

Electronic tongue based on potentiometry with various chemometric methods such as PLS (Partial Least Squares), LDA (Linear Discriminant Analysis), PCA (Principal Component Analysis), ANN (Artificial Neural Network) have been successfully applied in the qualitative analysis of honey, being used in botanical origin classification, but also in adulteration detection (Veloso et al., 2018; Major et al., 2011; Escriche et al., 2012). Against the electronic tongue based on potentiometry, the one based on voltammetry has various advantages such as: simplicity, low detection limits, ruggedness, long service life (Gan et al., 2016). The most used method is cyclic voltammetry, the results obtained being found in the form of a voltamogram that allows the characterization of the oxide-reduction process over a wide range of potential (Sobrino-Gregorio et al., 2018). The components of a cyclic voltammetry system are: potentiostat, electrolysis cell, current-voltage converter as well as a software for obtaining the results (Tiwari et al., 2012). Ropciuc et al. used cyclic voltammetry to detect adulterated honey by adding malt wort and inverted sugar, with gold and silver as the working electrodes. They concluded that the adulteration of honey produced significant changes by coupling electronic tongue with physico-chemical methods and PCA (Ropciuc et al., 2017).

The purpose of this paper is to detect adulterated honey samples with different types of syrups (corn, rice, inverted sugar, agave and maple) using the correlation between electronic tongue and physicochemical parameters.

\section{Materials and methods}

\section{Materials}

Raspberry honey was purchased from a beekeeper located in Suceava County, Romania. Five sugar syrups were used for honey adulteration: agave (Clarks, Mexic), maple (BioLogistic \& Distribution Partener, Canada), rice (Panaisia de Hadels GMBH Importing company, Korea), corn (Daesang Europe BV Importing company, Korea) and inverted sugar (obtained in laboratory from acid hydrolysis of sucrose).

Honey samples adulteration was done by adding syrup in different percentages: 5, 10, 20 and $50(\mathrm{w} / \mathrm{w})$. These adulteration percentages were chosen to observe the changes of the physicochemical parameters and voltammetric tongue data that appear depending on the proportion of adulteration agent (from a percentage of 5 to $50 \%$ ). ensure good homogeneity, the samples were kept at $50{ }^{\circ} \mathrm{C}$ for 24 hours.

\section{Physicochemical analysis}

The following physicochemical parameters were analyzed using Harmonised methods proposed by the International Honey Commission (Bogdanov et al, 2002): moisture content, $\mathrm{pH}$, free acidity, electrical conductivity and hiroxymethylfurfural content (HMF). 
The moisture content was determined on the basis of the refractive index of honey by conversion using a standard table (Chataway table). A drop of sample was placed on an Abbé refractometer (Leica Mark II Plus, Germany) which was previously calibrated with distilled water. The measurement was performed at $20^{\circ} \mathrm{C}$, the final result obtained being expressed as a percentage $(\%)$.

$\mathrm{pH}$ and free acidity were determined using an automatic Titroline device (SCHOTT instrument, Germany). $10 \mathrm{~g}$ of honey were dissolved in $75 \mathrm{ml}$ of distilled water; the $\mathrm{pH}$ was measured directly in solution and the free acidity was determined by titration with $0.1 \mathrm{M}$ sodium hydroxide solution to a $\mathrm{pH}$ of 8.30 . The calculation was performed using the following formula, the result being expressed in milliequivalents acid/kg honey:

$$
\text { Free acidity }=\mathrm{mL} \text { of } 0.1 \mathrm{M} \mathrm{NaOH} \times 10
$$

The electrical conductivity was measured using an XL 30 conductometer (Fisher Scientific, Germany). The analysis solution was prepared by dissolving $20 \mathrm{~g}$ of honey in 100 $\mathrm{ml}$ of distilled water. The results obtained were expressed in microSiemens per centimeter $(\mu \mathrm{S}$ $\left.\cdot \mathrm{cm}^{-1}\right)$.

The hydroxymethylfurfural (HMF) content was determined by the method proposed by White (White at el., 1979). The preparation of the samples was carried out as follows: $5 \mathrm{~g}$ of honey were dissolved in $25 \mathrm{~mL}$ of ultrapure water (Milli-Q, Merck Millipore). The solution was transferred to a $50 \mathrm{~mL}$ volumetric flask, over which $0.5 \mathrm{~mL}$ of Carrez I solution was added and mixed; then $0.5 \mathrm{~mL}$ of Carrez II solution was added and made up with ultrapure water. The resulting solution was filtered through filter paper and the first $10 \mathrm{~mL}$ of filtrate was removed. In two test tubes $5 \mathrm{~mL}$ of filtrate were introduced over which $5 \mathrm{~mL}$ of ultrapure water (in the first test tube) and $5 \mathrm{~mL}$ of $0.2 \%$ sodium bisulphite (in the second test tube representing the reference solution) were added. The absorbance of the sample solution against the reference solution at 284 and $336 \mathrm{~nm}$ was read using a UV-3600 spectrophotometer (Schimadzu Corporation, Japan). The HMF content was calculated using the following equation, the result being expressed in $\mathrm{mg} / \mathrm{kg}$ :

$$
\mathrm{HMF}(\mathrm{mg} / \mathrm{kg})=\left(\mathrm{A}_{284}-\mathrm{A}_{336}\right) \times 149.5 \times 5 \times \mathrm{D} / \mathrm{W},
$$

where: A284 - absorbance at $284 \mathrm{~nm}, \mathrm{~A} 336$ - absorbance at $336 \mathrm{~nm}, \mathrm{D}$ - dilution factor, W - weight of the honey sample (g).

Two instruments were used to measure the honey color: a photometer Pfund (Hanna Instruments, USA) and portable chromameter (Konica Minolta, Japan).

\section{Ciclyc voltammetry}

The measuring system was a PGSTAT with FRA32M module (Metrohm, Germany) coupled with three electrodes: reference electrode $(\mathrm{Ag} / \mathrm{AgCl})$, counter electrode (platinum) and working electrode (copper) (Metrohm, Germany). Data recording was done using a NOVA 2.0 software (Metrohm, Germany). The voltage was applied from $-1 \mathrm{~V}$ to $+1 \mathrm{~V}$, with a scan rate of $0.5 \mathrm{~V} / \mathrm{s}$.

The electrodes were immersed in honey solution $(8 \mathrm{~g}$ honey completed to $50 \mathrm{~mL}$ with deionized water). The data were read 5 minutes after introducing the electrodes into the solution, to achieve electrochemical balance (White et al., 2020). The copper electrode was cleaned by polishing with filter paper and rinsing with deionized water. All analysis were made in duplicates. 


\section{Statistical analysis}

In this study, Multi-factor Analysis of variance (ANOVA) using XLSTAT trial version (Microsoft, USA), was chosen as a method to highlight the differences between authentic and adulterated honey properties. Also, the results obtained were interpreted using Principal component analysis (PCA) - Unscrambler X software - version 10.1 (Camo, Norway). This statistical method was useful in clustering honey samples.

\section{Results and discussion}

\section{Physicochemical parameters}

Authentic and adulterated honey both exhibited different characteristics, all these data being useful in quality control. Adulteration agents significantly influenced almost all physicochemical parameters analyzed $(p<0.001)$. Depending on the degree of adulteration, significantly changes were for the $\mathrm{a}^{*}, \Delta \mathrm{E}^{*}$ parameters $(p<0.001)$ and moisture content $(p<0.01)$, for the rest the influence being insignificant $(p>0.05)$. The mean values of the physicochemical parameters for authentic and adulterated honey with the five types of agents as well as the means obtained depending on the degree of adulteration are shown in Tables 1 and 2.

Color of honey reported in CIE $\mathrm{L}^{*} \mathrm{a} \mathrm{b}^{*}$ space is represented by the following coordinates: $\mathrm{L}^{*}$ (lightness), $\mathrm{a}^{*}$ (red/green) and $\mathrm{b}^{*}$ (yellow/blue) (Kek et al., 2017). Both authentic honey and adulterated samples presenting the positive values for $\mathrm{a}^{*}$ and $\mathrm{b}^{*}$ coordinates, fit in the shades of red-orange-yellow (the first trigonometric quadrant). Adulterated honey with inverted sugar syrup presented the highest value of $L^{*}$ parameter (33.14), in opposite with the lowest value in case of adulterated honey with rice syrup (27.10). This increase of the lightness value of honey by adding inverted sugar was also observed by Ropciuc et al. (Ropciuc et al., 2017). Regarding the Pfund scale, the honey adulteration with agave and inverted sugar syrups led to a shade of extra light amber, while the adulterated samples with the other three types of syrups remained in the same color shade as the authentic honey (light amber), but with significant variations in values.

$\mathrm{pH}$ influences the texture and stability of honey having an important role during its extraction and storage (Özcan et al., 2006). It also indicates a possible microbial growth, especially for mold and yeast (at pH 4-4.5 they can survive) (Ismail et al., 2019). The pH of all the honey samples analyzed was acidic. Adulterated honey with inverted sugar syrup decrease its value due to the presence of added citric acid. The decrease of $\mathrm{pH}$ value was observed not only in adulterated honey with inverted sugar but also in the one adulterated with malt wort, glucose and hydrolyzed inulin syrup (Oroian et al., 2018). In the case of adulterated honey with other types of syrups studied, the $\mathrm{pH}$ value showed a significant increase.

Fermentation of sugars with alcohol formation, produced under the action of microorganisms, followed by oxidation and formation of carboxylic acids lead to a high free acidity (Almeida-Muradian et al., 2007). Adulterated honey samples with rice syrup were the only ones that showed a higher free acidity $(12.81 \mathrm{meq} / \mathrm{kg})$ compared to authentic honey $(10.40$ $\mathrm{meq} / \mathrm{kg}$ ). None of the samples showed free acidity higher than $50 \mathrm{meq} / \mathrm{kg}$.

The electrical conductivity depends on the content of proteins and mineral salts, providing information about the botanical origin of honey (Stihi et al., 2016). Inverted sugar, agave and corn syrups produced a decrease of electrical conductivity, while maple and rice syrups significantly increased its value. Ropciuc et al. also, observed a decrease of the electrical conductivity of adulterated honey with inverted sugar (Ropciuc et al., 2017) 
Table 1

ANOVA of physicochemical parameters of authentic and adulterated raspberry honey with agave, corn, inverted sugar, maple and rice syrups

\begin{tabular}{|c|c|c|c|c|c|c|c|}
\hline \multirow[t]{2}{*}{ Parameter } & \multicolumn{6}{|c|}{ Adulteration agent } & \multirow[t]{2}{*}{$F$-ratio } \\
\hline & Authentic & Agave & Corn & $\begin{array}{c}\text { Inverted } \\
\text { sugar }\end{array}$ & Maple & Rice & \\
\hline $\mathbf{L}^{*}$ & $30.26 \mathrm{~b}$ & $32.83 \mathrm{c}$ & $30.90 \mathrm{bc}$ & $33.14 \mathrm{c}$ & $27.48 \mathrm{a}$ & $27.10 \mathrm{a}$ & $13.25 * * *$ \\
\hline$a^{*}$ & $6.83 \mathrm{a}$ & $7.90 \mathrm{a}$ & $6.72 \mathrm{a}$ & $8.07 \mathrm{ab}$ & $9.41 \mathrm{~b}$ & $7.48 \mathrm{a}$ & $3.02 *$ \\
\hline $\mathbf{b}^{*}$ & $30.34 \mathrm{c}$ & $23.72 b$ & $21.69 \mathrm{~b}$ & $24.27 \mathrm{~b}$ & $15.94 a$ & $14.60 \mathrm{a}$ & $19.05 * * *$ \\
\hline$\Delta \mathbf{E}^{*}$ & $0 \mathrm{a}$ & $5.63 c$ & $2.41 \mathrm{ab}$ & $5.26 \mathrm{bc}$ & $6.48 \mathrm{c}$ & $7.65 \mathrm{c}$ & $4.40 * *$ \\
\hline $\begin{array}{c}\text { Pfund (mm } \\
\text { Pfund) }\end{array}$ & $57.75 \mathrm{abc}$ & $49.75 \mathrm{a}$ & $55.69 \mathrm{ab}$ & $49.83 \mathrm{a}$ & $70.46 \mathrm{c}$ & $65.09 \mathrm{bc}$ & $5.75 * * *$ \\
\hline pH & $4.05 \mathrm{a}$ & $4.09 \mathrm{a}$ & $4.14 \mathrm{a}$ & $3.97 \mathrm{a}$ & $4.62 \mathrm{~b}$ & $4.18 \mathrm{a}$ & $7.19 * * *$ \\
\hline $\begin{array}{c}\text { Free acidity } \\
\text { (meq/kg) }\end{array}$ & $10.40 \mathrm{a}$ & $8.86 \mathrm{a}$ & $8.90 \mathrm{a}$ & $9.53 \mathrm{a}$ & $8.86 \mathrm{a}$ & $12.81 \mathrm{~b}$ & $9.26 * * *$ \\
\hline $\begin{array}{c}\text { Electrical } \\
\text { conductivity } \\
(\mu \mathrm{S} / \mathrm{cm})\end{array}$ & $233.97 \mathrm{ab}$ & $191.19 \mathrm{a}$ & $187.74 a$ & $203.78 \mathrm{a}$ & $455.98 \mathrm{c}$ & $322.61 b$ & $9.46 * * *$ \\
\hline $\begin{array}{c}\text { Moisture } \\
\text { content (\%) }\end{array}$ & $16.16 \mathrm{a}$ & $17.56 \mathrm{a}$ & $17.40 \mathrm{a}$ & $16.49 \mathrm{a}$ & $19.57 b$ & $26.40 \mathrm{a}$ & $4.74 * *$ \\
\hline $\begin{array}{c}\text { HMF } \\
(\mathrm{mg} / \mathrm{kg})\end{array}$ & $58.09 \mathrm{a}$ & $70.66 a$ & $46.35 \mathrm{a}$ & $185.07 \mathrm{~b}$ & $46.50 \mathrm{a}$ & $51.54 \mathrm{a}$ & $9.19 * * *$ \\
\hline
\end{tabular}

Means followed by different letters in the same rows are significantly different $(\mathrm{p}<0.05)$

Table 2

ANOVA of physicochemical parameters of authentic and adulterated raspberry honey in different percentages with syrup

\begin{tabular}{|c|c|c|c|c|c|c|}
\hline \multirow{2}{*}{ Parameter } & \multicolumn{5}{|c|}{ Percentage } & \multirow{2}{*}{$\boldsymbol{F}$-ratio } \\
\cline { 2 - 6 } $\mathbf{L}^{*}$ & $\mathbf{0 \%}$ & $\mathbf{5 \%}$ & $\mathbf{1 0 \%}$ & $\mathbf{2 0 \%}$ & $\mathbf{5 0 \%}$ & \\
\hline $\mathbf{a}^{*}$ & $6.83 \mathrm{ab}$ & $9.18 \mathrm{c}$ & $8.44 \mathrm{bc}$ & $7.99 \mathrm{~b}$ & $6.04 \mathrm{a}$ & $9.15^{* * *}$ \\
\hline $\mathbf{b}^{*}$ & $30.34 \mathrm{~b}$ & $21.24 \mathrm{a}$ & $20.00 \mathrm{a}$ & $19.55 \mathrm{a}$ & $19.38 \mathrm{a}$ & $2.18 \mathrm{~ns}$ \\
\hline$\Delta \mathbf{E}^{*}$ & $0 \mathrm{a}$ & $4.12 \mathrm{ab}$ & $3.98 \mathrm{ab}$ & $5.15 \mathrm{~b}$ & $8.68 \mathrm{c}$ & $6.90 * * *$ \\
\hline $\begin{array}{c}\text { Pfund (mm } \\
\text { Pfund) }\end{array}$ & $57.75 \mathrm{a}$ & $61.58 \mathrm{a}$ & $60.85 \mathrm{a}$ & $59.20 \mathrm{a}$ & $51.02 \mathrm{a}$ & $1.19 \mathrm{~ns}$ \\
\hline $\mathbf{p H}$ & $4.05 \mathrm{a}$ & $4.08 \mathrm{a}$ & $4.12 \mathrm{a}$ & $4.19 \mathrm{a}$ & $4.40 \mathrm{a}$ & $1.79 \mathrm{~ns}$ \\
\hline $\begin{array}{c}\text { Free acidity } \\
\text { (meq/kg) }\end{array}$ & $10.40 \mathrm{a}$ & $10.25 \mathrm{a}$ & $10.11 \mathrm{a}$ & $9.83 \mathrm{a}$ & $8.98 \mathrm{a}$ & $0.61 \mathrm{~ns}$ \\
\hline $\begin{array}{c}\text { Electrical } \\
\text { conductivity } \\
(\boldsymbol{\mu S} / \mathbf{c m})\end{array}$ & $233.97 \mathrm{a}$ & $242.98 \mathrm{a}$ & $251.99 \mathrm{a}$ & $270.00 \mathrm{a}$ & $324.06 \mathrm{a}$ & $0.53 \mathrm{~ns}$ \\
\hline $\begin{array}{c}\text { Moisture } \\
\text { content (\%) }\end{array}$ & $16.16 \mathrm{a}$ & $16.47 \mathrm{a}$ & $16.78 \mathrm{a}$ & $17.41 \mathrm{a}$ & $19.28 \mathrm{~b}$ & $5.33 * *$ \\
\hline HMF (mg/kg) & $58.09 \mathrm{a}$ & $63.25 \mathrm{a}$ & $68.41 \mathrm{a}$ & $78.74 \mathrm{a}$ & $109.70 \mathrm{~b}$ & $0.68 \mathrm{~ns}$ \\
\hline
\end{tabular}

Means followed by different letters in the same rows are significantly different $(\mathrm{p}<0.05)$ 


\section{- Food Technology -}

The moisture content shows the degree of aging of the honey and its ability to remain stable throughout storage (Sudzina et al., 2009), a high content facilitating the fermentation process (Czipa et al., 2019). Depending on the degree of adulteration the moisture content increased from $16.16 \%$ in authentic honey to $19.28 \%$ in adulterated honey with $50 \%$ syrup. Depending on the agent used, maple syrup produced the highest increase $(26.40 \%)$, exceeding the maximum limit of $20 \%$. The increase of the moisture content was observed not only by the addition of corn syrup in pure honey but also in the case of high fructose corn syrup (Ribeiro et al., 2009).

Fresh honey has small amounts or even traces of HMF, the formation being slow as long as the storage period and temperature are appropriate. Temperature exposure as well as honey adulterated with inverted sugar syrup lead to the formation of a high amount of HMF (Czipa et al., 2019). The same observation can be made by us, the adulteration with inverted sugar syrup led to a high increase in the value of HMF content (from $58.09 \mathrm{mg} / \mathrm{kg}$ in authentic honey to $185.07 \mathrm{mg} / \mathrm{kg}$ in adulterated honey). Depending on the degree of adulteration, the HMF content increased with the increase of the percentage of added syrup. Agave syrup, also, produced an increase in HMF content $(70.66 \mathrm{mg} / \mathrm{kg})$. All honey samples exceeded the maximum allowed limit of $40 \mathrm{mg} / \mathrm{kg}$.

\section{Voltammetric tongue}

Figure 1 shows the voltammograms group made for authentic honey, pure syrups and adulterated honey samples. It is clearly observed that honey adulteration has significantly influenced the parameters of voltametric tongue. There are changes in current intensity that occur depending on the adulteration agent but also depending on the degree of adulteration. The current intensity value for authentic honey was $0.192 \mathrm{~mA}$. Regarding pure syrup, the highest values were for maple and rice syrups and the lowest were for the other three types of syrup. Thus, significant increases are observed in the case of adulterated honey with $50 \%$ maple syrup $(0.419 \mathrm{~mA})$ and $50 \%$ rice syrup $(0.283 \mathrm{~mA})$. At the same time, significant decreases in current intensity values compared to authentic honey were in the case of adulterated honey with $50 \%$ inverted sugar syrup $(0.068 \mathrm{~mA}), 50 \%$ corn syrup $(0.047 \mathrm{~mA})$ and $50 \%$ agave syrup $(0.045 \mathrm{~mA})$. Regardless of the adulteration agent used, with the copper electrode the variation of the current intensity were highlighted starting from the adulteration degree of $5 \%$. 

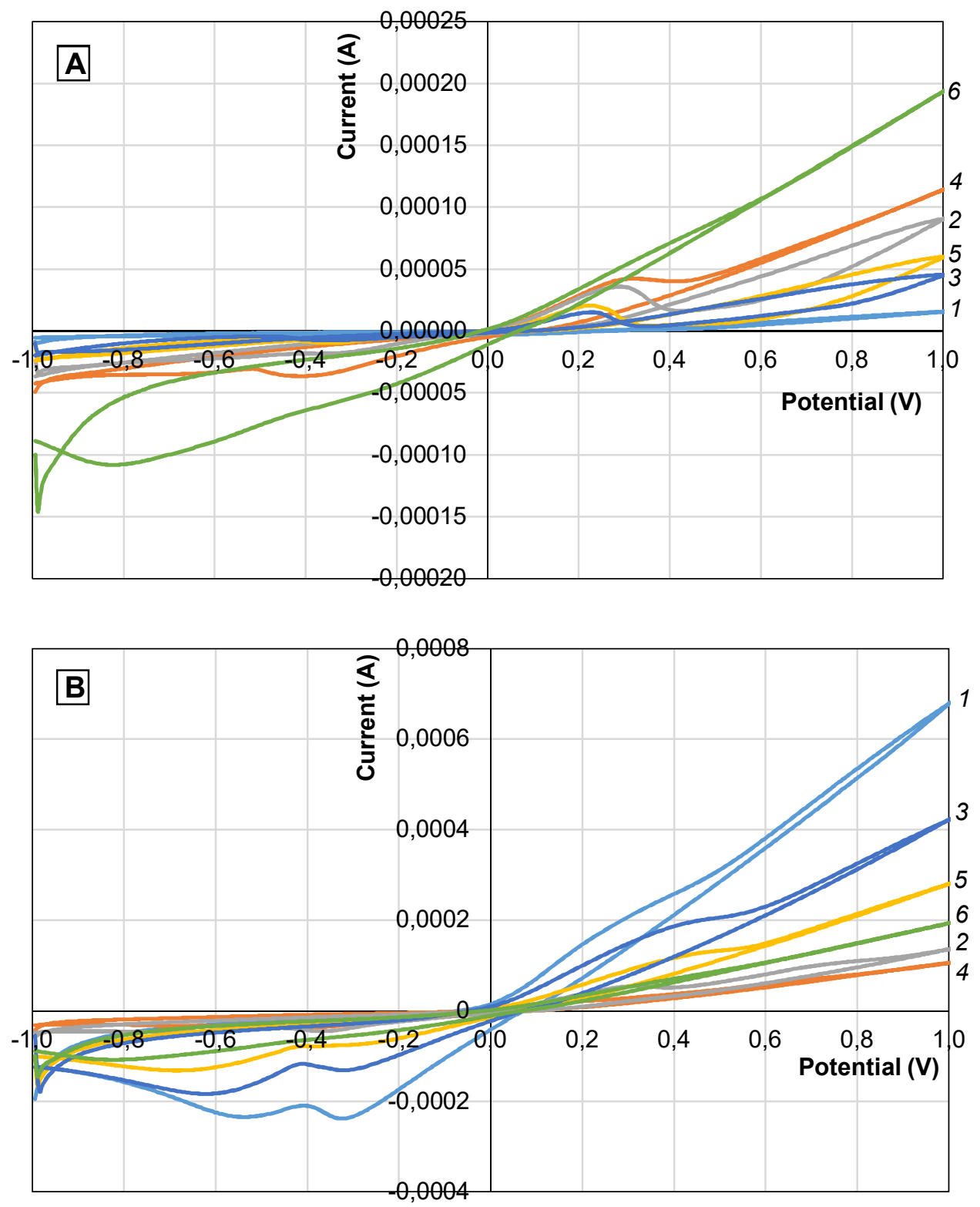

Figure 1. Cyclic voltammograms (using copper as working electrode) of authentic raspberry honey, pure syrups and honey adulterated with:

(A) - agave syrup, (B) - maple syrup, (C) - rice syrup,

(D) - corn syrup and (E) - inverted sugar syrup in 5, 10, 20 and 50

1 - Agave syrup

2 - Honey adulteration $10 \%$

3 - Honey adulteration $50 \%$
$4-$ Honey adulteration $5 \%$

5 - Honey adulteration $20 \%$

6 Raspberry honey 

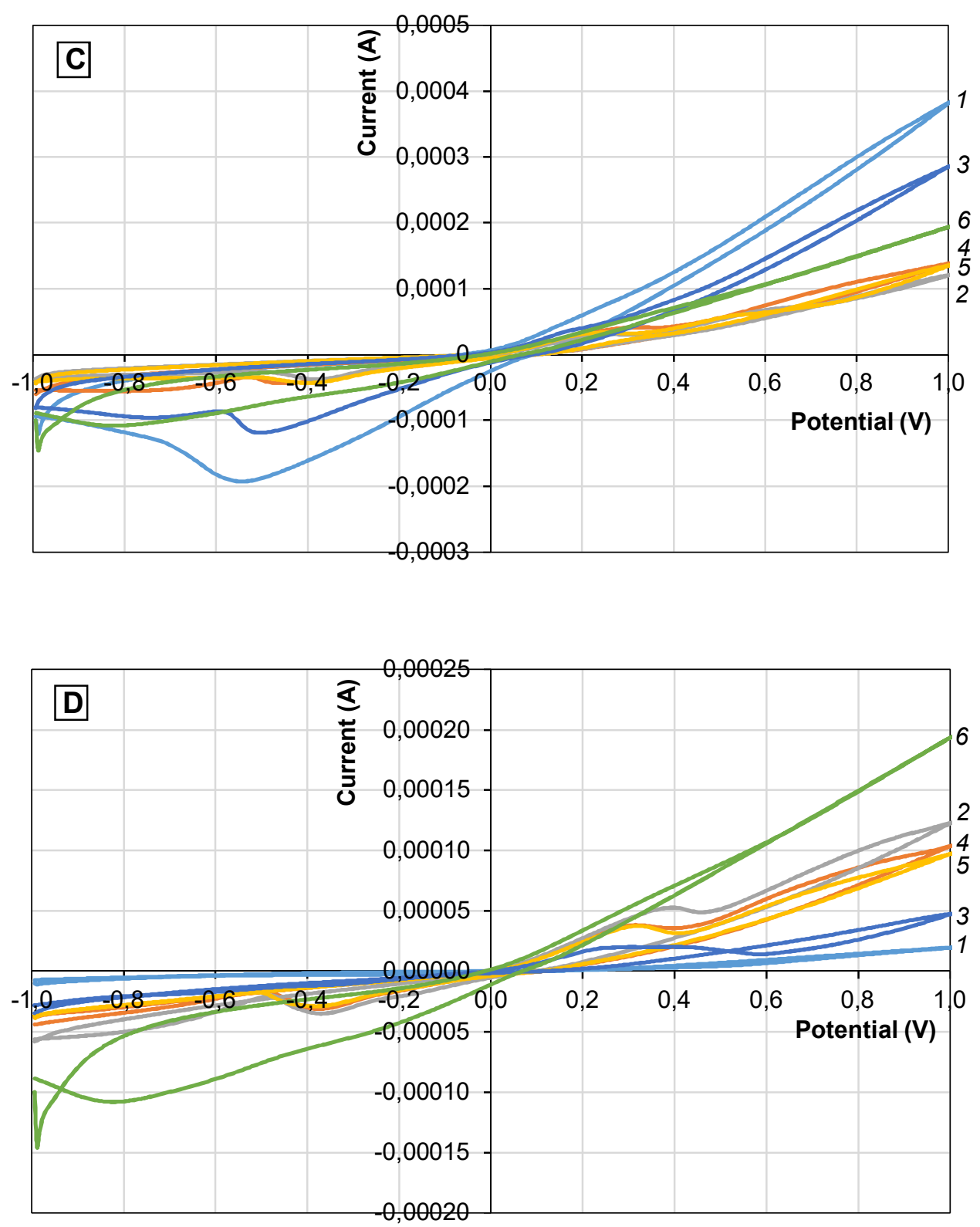

Figure 1 (Continue). Cyclic voltammograms (using copper as working electrode) of authentic raspberry honey, pure syrups and honey adulterated with:

(A) - agave syrup, (B) - maple syrup, (C) - rice syrup,

(D) - corn syrup and (E) - inverted sugar syrup in 5, 10, 20 and 50

$1-$ Agave syrup

2 - Honey adulteration $10 \%$

3 - Honey adulteration $50 \%$
$4-$ Honey adulteration 5\%

5 - Honey adulteration $20 \%$

6 -Raspberry honey 


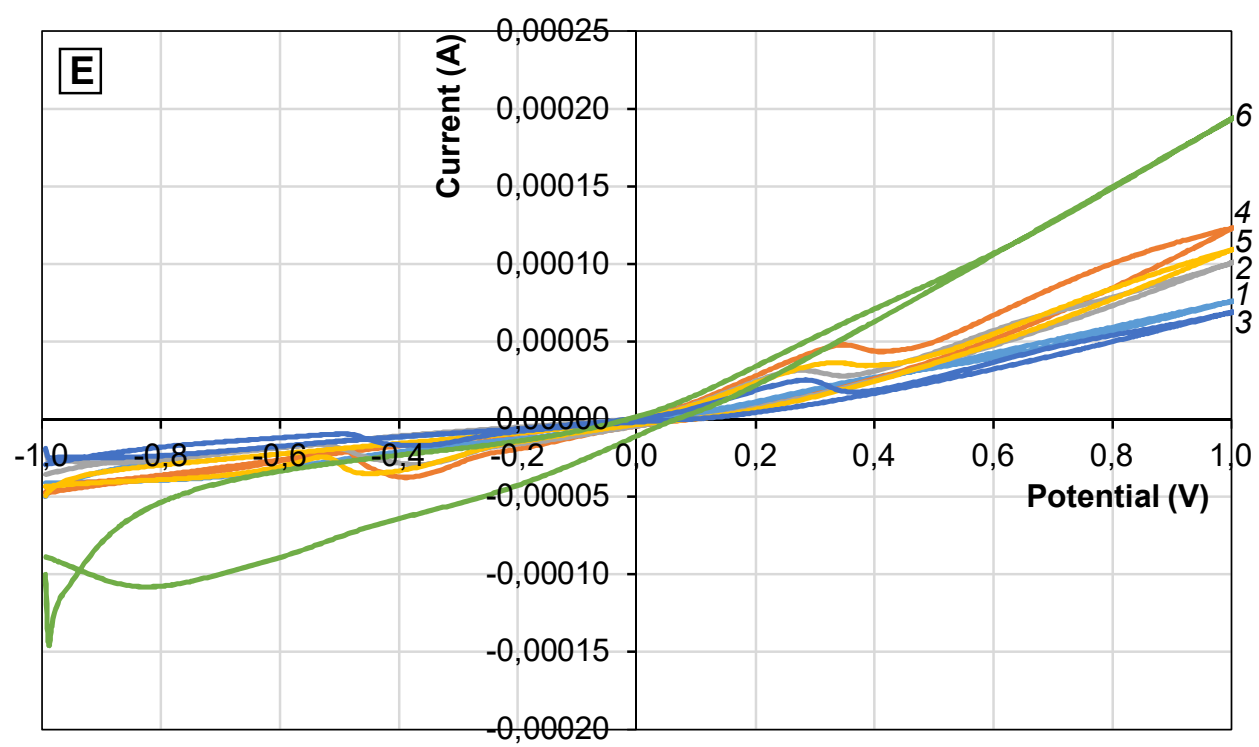

Figure 1 (Continue). Cyclic voltammograms (using copper as working electrode) of authentic raspberry honey, pure syrups and honey adulterated with:

(A) - agave syrup, (B) - maple syrup, (C) - rice syrup,

(D) - corn syrup and (E) - inverted sugar syrup in 5, 10, 20 and 50

1 Agave syrup

2 - Honey adulteration $10 \%$

3 - Honey adulteration $50 \%$

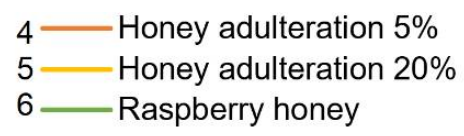

\section{Principal component analysis}

Principal component analysis (PCA) is used to reduce experimental data to two main components. Thus, the first component (PC-1) represented $88 \%$ of the variance and the second component (PC-2) $11 \%$, totaling $99 \%$ of the initial variability. As can be seen in Figure 2, agave and corn syrups best mimics the characteristics of authentic honey. The samples of adulterated honey with 5\%,10\% and $20 \%$ agave syrup, $5 \%$ and $10 \%$ corn syrup as well as 5\% maple syrup are close to authentic honey. Adulterated honey samples with both inverted sugar syrup and rice syrup are found in other dials, due to their chemical composition. At the same time, there is a similarity of the chemical composition between adulterated honey samples with inverted sugar and maple syrups $(5 \%$ with $10 \%, 10 \%$ with $20 \%$ and $20 \%$ with $50 \%$ inverted sugar syrup - maple syrup). According to Principal component analysis - loadings (Figure 3 ) the color parameters $\left(L^{*}, a^{*}, b^{*}\right)$, Pfund, free acidity, $\mathrm{pH}$, moisture content are correlated with $\mathrm{Cu}^{-}$and $\mathrm{E}^{*}$ parameter, $\mathrm{HMF}$ content and electrical conductivity are correlated with $\mathrm{Cu}^{+}$. 


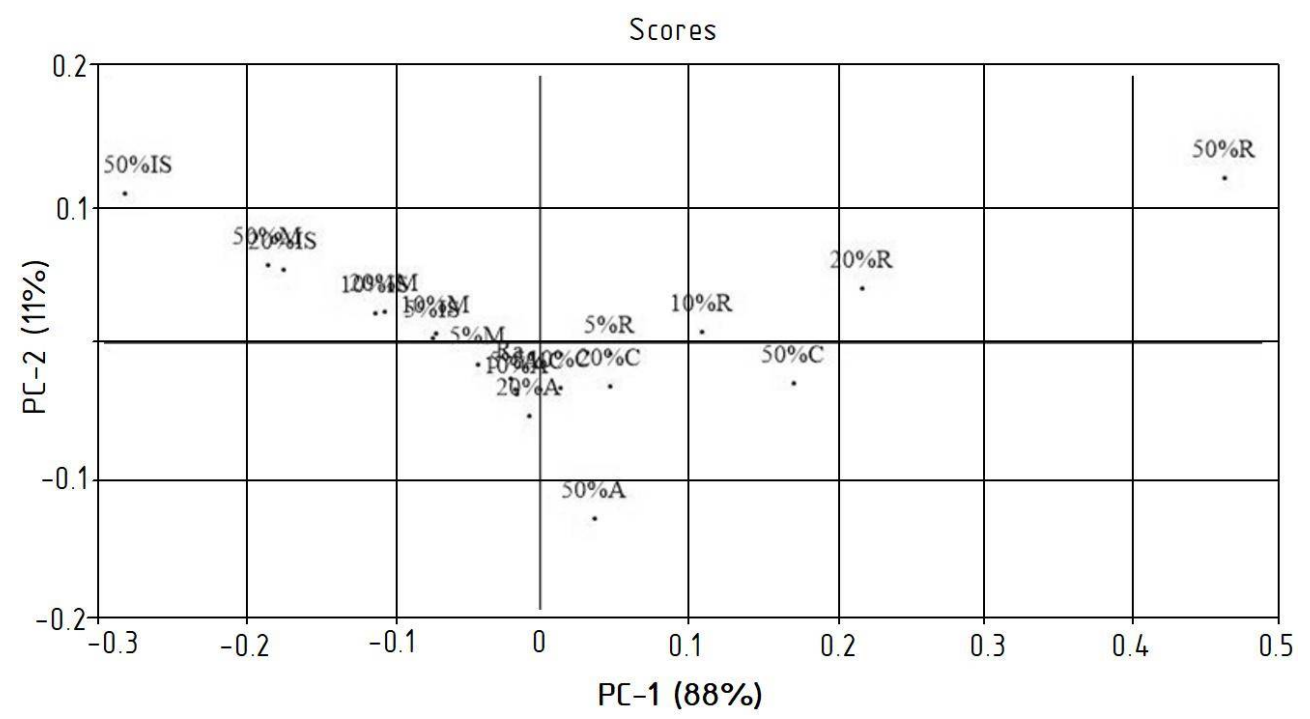

Figure 2. Principal component analysis - scores:

Ra - raspberry honey, A - agave syrup, $\mathbf{C}$ - corn syrup, IS - inverted sugar syrup, $M$ - maple syrup, $R$ - rice syrup, 5, 10, 20 and 50\% - degree of adulteration

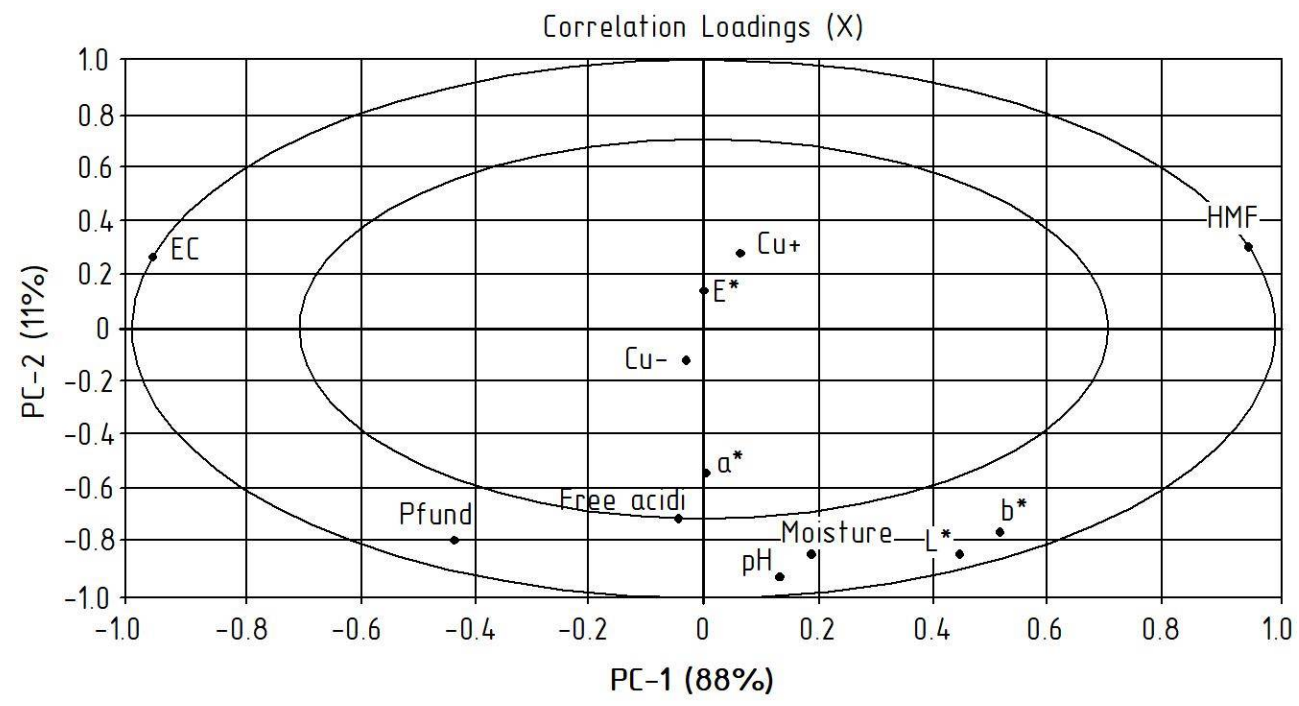

Figure 3. Principal component analysis - loadings

Other researchers have also successfully used voltammetric tongue made of various metallic electrodes both in authentication of geographical and botanical origins and in detection of adulterated honey with sugar syrups. Pauliuc et al. performed the authentication of raspberry honey with voltammetric tongue using five working electrodes ( $\mathrm{Pt}, \mathrm{Au}, \mathrm{Ag}, \mathrm{TiO}$, $\mathrm{ZnO}$ and glass electrode). Using LDA, cross-validated grouped cases were in a percentage of $66.7 \%$ (Pauliuc et al., 2020). Electronic tongue system consisting of seven electrodes, 
including $\mathrm{Cu}$, was used to differentiate honey samples according to botanical and geographical origin but also to detect glucose and saccharose syrups in honey even in a percentage of $2 \%$. SVMs (Support Vector Machines) and HCA (Hierarchical Cluster Analysis) showed a success rate in the recognition of adulterated honey of $100 \%$, while PCA only $86.03 \%$ for adulterated honey with glucose syrup and $86.37 \%$ for adulterated honey with saccharose syrup (Bougrini et el., 2016). Another electrochemical system with the glassy carbon as working electrode was used to detect adulterated honey with rice syrup. The $100 \%$ recognition rate was achieved using PCA-LDA (Cai et al., 2013). Sobrino-Gregorio et al. used electronic tongue made of four electrodes ( $\mathrm{Au}, \mathrm{Pt}, \mathrm{Ir}, \mathrm{Rh})$ to detect adulterated honey with barley, brown rice and corn syrups. The PCA analysis was able to differentiate the types of pure honey and syrups but also to discriminate the adulterated honey samples in different percentages and the PLS models were an essential tool in quantifying the level of adulteration (Sobrino-Gregorio et al., 2018). The voltammetric tongue consisting in gold and silver electrodes as working electrodes with physicochemical parameters and PCA were used in the detection of adulterated honeydew with inverted sugar syrup. The adulterated samples with $5 \%$ and $10 \%$ syrup were placed near the authentic samples, thus resulting that at lower percentages of adulteration the changes are less significant (Ropciuc et al., 2017). Likewise, the combination of the electronic tongue with physicochemical parameters led to a correct classification of $96.66 \%$ of the honey samples of different botanical origins (accacia, tillia, sunflower, honeydew, polyfloral) adulterated with glucose, fructose and invert sugar (Oroian et al., 2018).

\section{Conclusion}

1. Electronic tongue is a simple and fast method. The development of this method by testing different electrodes as well as other types of honey leads to an increase in effectiveness.

2. Physicochemical parameters (color, $\mathrm{pH}$, free acidity, electrical conductivity, HMF content) can be used as a preliminary analysis, but by coupling the voltammetric tongue with it have proven their usefulness in detecting adulterated honey samples with different adulteration agents even at $5 \%$.

3. Using Principal component analysis (PCA) in clustering honey samples it was observed that samples with $5 \%, 10 \%$ and $20 \%$ agave syrup, $5 \%$ and $10 \%$ corn syrup as well as $5 \%$ maple syrup are placed near to the authentic raspberry sample. Thus, we can conclude that these types of syrups added in small quantities present physicochemical and voltammetric tongue parameters closed to the authentic honey.

Acknowledgements: This work was supported by a grant of the Romanian Ministry of Education and Research, CNCS-UEFISCDI, project number PN-III-P1-1.1-TE-2019-0583.

\section{References}

Almeida-Muradian L.B.D., Matsuda A.H., \& Bastos D.H.M. (2007), Physicochemical parameters of Amazon Melipona honey, Química nova, 30(3), pp. 707-708. 
Bogdanov, S., Martin, P., \& Lullmann, C. (2002), Harmonised methods of the international honey commission, Swiss Bee Research Centre, FAM, Liebefeld.

Bougrini M., Tahri K., Saidi T., El Hassani N.E.A., Bouchikhi B., \& El Bari N. (2016), Classification of honey according to geographical and botanical origins and detection of its adulteration using voltammetric electronic tongue, Food Analytical Methods, 9(8), pp. 2161-2173.

Bougrini M., Tahri K., Saidi T., El Hassani N. E. A., Bouchikhi B., \& El Bari N. (2016), Classification of honey according to geographical and botanical origins and detection of its adulteration using voltammetric electronic tongue, Food Analytical Methods, 9(8), pp. 2161-2173.

Cai J., Wu X., Yuan L., Han E., Zhou L., \& Zhou A. (2013), Determination of Chinese Angelica honey adulterated with rice syrup by an electrochemical sensor and chemometrics, Analytical Methods, 5(9), pp. 2324-2328.

Czipa N., Phillips C. J., \& Kovács B. (2019), Composition of acacia honeys following processing, storage and adulteration, Journal of food science and technology, 56(3), pp. 1245-1255.

Escriche I., Kadar M., Domenech E., \& Gil-Sanchez L. (2012), A potentiometric electronic tongue for the discrimination of honey according to the botanical origin. Comparison with traditional methodologies: Physicochemical parameters and volatile profile, Journal of Food Engineering, 109(3), pp. 449-456.

Gan Z., Yang Y., Li J., Wen X., Zhu M., Jiang Y., \& Ni Y. (2016), Using sensor and spectral analysis to classify botanical origin and determine adulteration of raw honey, Journal of Food Engineering, 178, pp. 151-158.

Ha, D., Sun, Q., Su, K., Wan, H., Li, H., Xu, N., ... \& Wang, P. (2015), Recent achievements in electronic tongue and bioelectronic tongue as taste sensors, Sensors and Actuators B: Chemical, 207, pp. 1136-1146.

Ismail N. I., Kadir M. R. A., Mohamed M., \& Zulkifli R. M. (2019), Effects of Sugar Adulterants on the Physicochemical Properties of Natural Honey, Journal of Tomography System \& Sensors Application, 2(2).

Kek S. P., Chin N. L., Yusof Y. A., Tan S. W., \& Chua L. S. (2017), Classification of entomological origin of honey based on its physicochemical and antioxidant properties, International Journal of Food Properties, 20(sup3), S2723-S2738.

Major N., Marković K., Krpan M., Šarić G., Hruškar M., \& Vahčić N. (2011), Rapid honey characterization and botanical classification by an electronic tongue, Talanta, 85(1), pp. 569-574.

Oroian M., Paduret S., \& Ropciuc S. (2018), Honey adulteration detection: voltammetric e-tongue versus official methods for physicochemical parameter determination, Journal of the Science of Food and Agriculture, 98(11), pp. 4304-4311.

Oroian M., Ropciuc S., \& Dranca F. (2018), Honey adulteration detection using instrumental techniques.

Özcan M., Arslan D., \& Ceylan D. A. (2006), Effect of inverted saccharose on some properties of honey, Food chemistry, 99(1), pp. 24-29.

Pauliuc D., Dranca F., \& Oroian M. (2020), Raspberry, Rape, Thyme, Sunflower and Mint Honeys Authentication Using Voltammetric Tongue, Sensors, 20(9), p. 2565.

Peris M., \& Escuder-Gilabert L. (2016), Electronic noses and tongues to assess food authenticity and adulteration, Trends in Food Science \& Technology, 58, pp. 40-54.

Ribeiro R.D.O.R., Mársico E.T., da Silva Carneiro C., Monteiro M.L.G., Júnior C.C., \& de Jesus E.F.O. (2014), Detection of honey adulteration of high fructose corn syrup by Low Field Nuclear Magnetic Resonance (LF 1H NMR), Journal of Food Engineering, 135, pp. 39-43.

Ropciuc S., Oroian M., Pădureț S., \& Buculei A. (2017), Honeydew honey adulteration: E-tongue and physico-chemical analyses, Food and Environment Safety Journal, 16(2), 
Shimizu F. M., Braunger M. L., Riul Jr. A., \& Oliveira Jr. O. N. (2020), Electronic Tongues. Smart Sensors for Environmental and Medical Applications, pp. 61-80.

Sobrino[Gregorio L., Bataller R., Soto J., \& Escriche I. (2018), Monitoring honey adulteration with sugar syrups using an automatic pulse voltammetric electronic tongue, Food Control, 91, pp. 254-260.

Stihi C.L.A.U.D.I.A., Chelarescu E.D., Duliu, O.G., \& Toma L.G. (2016), Characterization of Romanian honey using physico-chemical parameters and the elemental content determined by analytical techniques, Romanian reports in Physics, 68(1), pp. 362-369.

Sudzina M., Melich, M., Kňazovická, V., Felšöciová, S., Kociubinski, G. L., Andreji, J., ... \& Kráčmar, S. (2009), Physicochemical characterization of natural honeys from different regions in Slovakia, Acta Universitatis Agriculturae et Silviculturae Mendelianae Brunensis, p. 57.

Tiwari K., Tudu B., Bandhopadhya R., \& Chatterjee A. (2012, March), Discrimination of monofloral honey using cyclic voltammetry. In 2012 3rd National Conference on Emerging Trends and Applications in Computer Science, IEEE, pp. 132-136.

Veloso A. C., Sousa M. E., Estevinho L., Dias L. G., \& Peres A. M. (2018), Honey evaluation using electronic tongues: An overview, Chemosensors, 6(3), p. 28.

White Jr.J.W. (1979), Spectrophotometric method for hydroxymethylfurfural in honey, Journal of the Association of Official Analytical Chemists, 62(3), pp. 509-514. 